\title{
Efektifitas Penurunan Kadar Kafein pada Teh Hitam dengan Metode Ekstraksi
}

\author{
Andi Muhamad Iqbal Akbar Asfar ${ }^{1, \mathrm{a}}$ \\ ${ }^{1}$ Jurusan Teknik Kimia, Politeknik Negeri Ujung Pandang, Jl. Perintis Kemerdekaan KM. 10 \\ Tamalanrea, Makassar, Indonesia 90245 \\ a andiifalasfar@gmail.com
}

\begin{abstract}
Black tea is a tea that is currently the most widely consumed by the people of Indonesia. Consumption of black tea more than two cups per day can affect in human healthy because tea contains $20-90 \mathrm{mg}$ of caffeine per cup, while the maximum consumption of caffeine is $150 \mathrm{mg}$ per day and the maximum limit of caffeine is $0.02 \%$ in food and beverages. The method used in this study is the method of soxhlet extraction by varying the ethyl alcohol as solvent are $10 \%, 20 \%, 30 \%, 40 \%$, and $50 \%$ with 2.5 hours extraction time. The initial caffeine content in black tea samples was $3.97 \%$, after extraction decreased significantly levels of caffeine on $50 \%$ ethyl alcohol concentration is $0,0199 \%$. The extraction method using Soxhlet technique is very effective to reduce caffeine in black tea.
\end{abstract}

Keywords—black tea; soxhlet extraction; caffeine

\begin{abstract}
Abstrak-Teh hitam merupakan teh yang saat ini paling banyak dikonsumsi oleh masyarakat Indonesia. Konsumsi seduhan teh hitam melebihi dua cangkir per hari dapat mengakibatkan dampak terhadap kesehatan sebab teh mengandung 20-90 mg kafein per cangkir, sedangkan batas maksimum konsumsi kafein adalah $150 \mathrm{mg}$ per hari dan batas maksimum kafein adalah $0,02 \%$ pada makanan dan minuman. Metode yang digunakan dalam penelitian ini adalah metode ekstraksi sokletasi dengan memvariasikan pelarut etil alcohol yaitu $10 \%, 20 \%, 30 \%, 40 \%$, dan $50 \%$ dengan waktu ekstraksi 2,5 jam. Kadar kafein awal pada sampel teh hitam adalah 3,97\%, setelah dilakukan ekstraksi mengalami penurunan kadar kafein yang cukup signifikan pada variasi konsentrasi etil alcohol $\mathbf{5 0 \%}$ yaitu 0,0199\%. Metode ekstraksi menggunakan Teknik soklet sangat efektif menurunkan kadar kafein pada teh hitam.
\end{abstract}

Kata Kunci-teh hitam; sokletasi; kafein

\section{Pendahuluan}

Teh hitam yang dikenal dengan Camellia sinensis merupakan tanaman yang paling banyak dikonsumsi sebagai minuman. Sekitar $78 \%$ teh hitam dikonsumsi oleh masyarakat Indonesia khususnya masyarakat Sulawesi Selatan. Teh hitam memiliki cita rasa khas dengan warna dan berasa tajam yang dihasilkan ketika proses fermentasi dilakukan akibat adanya proses oksidasi oleh enzim katekin atau disebut dengan polyphenol [1]. Kandungan katekin dalam teh berkisar $75-80 \%$ [2].

Konsumsi teh melebihi dua cangkir per hari sangat beresiko terhadap kesehatan peminumnya sebab teh mengandung 40-100 $\mathrm{mg}$ kafein per cangkir. Kandungan kafein pada teh dalam 100 gram terdapat 2,5-4,5\% kafein atau kandungan kafein berkisar 20-90 mg khusus pada teh hitam [3] atau sekitar $8-11 \%$ berat kering untuk $40 \mathrm{mg}$ kafein per $235 \mathrm{ml}$ cangkir [4]. Berdasarkan FDA (Food Drug Adminstration) yang diizinkan adalah 100-200 mg/hari, sedangkan menurut SNI 01-7152-2006 bahwa batas maksimum kafein dalam makanan dan minuman adalah $150 \mathrm{mg} /$ hari [5]. Efek farmakologi dari adanya kelebihan kafein akan memengaruhi system saraf pusat, jantung, perifer, pusat vaskulatur, ginjal, gastrointestinal serta system pernafasan [6][7]. Akan tetapi jika dimanfaatkan dengan kadar yang sesuai maka kafein berguna untuk anti hipertensi, anti inflamasi, anti obesitas, hypocholesterolemic, dan anti diabetes [8].

Kafein (1,3,5-trimethylxanthine) dalam bentuk murni sebagai kristal putih, memiliki massa molar 194,19 gram/mol, mudah larut dalam air dan dalam banyak pelarut organik dan meleleh pada suhu $234^{\circ} \mathrm{C}-239^{\circ} \mathrm{C}$ [9]. Penilitian ini melakukan metode ekstraksi dalam menurunkan kadar kafein pada teh hitam dengan menentukan konsentrasi pelarut etil alkohol yang paling efektif. 


\section{Metode Penelitian}

\section{A. Metode}

Metode yang digunakan dalam penelitian ini adalah metode ekstraksi dengan teknik sokletasi. Variasi pelarut etil alkohol dilakukan dengan lima variasi yaitu $10 \%$, $20 \%, 30 \%, 40 \%$, dan $50 \%$ pada kondisi operasi 2,5 jam.

1. Alat

Beaker Gelas $250 \mathrm{ml} \& 50 \mathrm{ml}$, gelas ukur $100 \mathrm{ml} \& 600$ ml, Labu ukur $500 \mathrm{ml} \& 100 \mathrm{ml}$, cawan petridish, kaca arloji, seperangkat alat ekstraksi, oven, timbangan analitik, oil bath, kertas saring, corong pisah $250 \mathrm{ml}$, tanur, pengering vakum dan hot plate.

\section{Bahan}

Bahan yang digunakan adalah Teh hitam. Etanol 96\%, $\mathrm{NaOH} 0,001 \%, \mathrm{CHCl}_{3}, \mathrm{CaCO}_{3}$ padat, $\mathrm{H}_{2} \mathrm{SO}_{4} 98 \%$, Akuades, Kantong Soklet dan alat ekstraksi soklet, dan aluminium foil.

\section{B. Prosedur Penelitian}

Prosedur penelitian terdiri atas 2 prosedur yaitu penentuan kadar kafein awal sampel teh hitam dan penentuan kadar kafein setelah proses ekstraksi sokletasi dilakukan.

1. Analisa kadar kafein awal teh hitam

Teh hitam diuji kadar kafeinnya untuk mengetahui kadar kafein awal teh hitam yang digunakan sebagai sampel penelitian.

2. Analisa kadar kafein teh setelah ekstraksi

Prosedur ini sama dengan prosedur untuk analisa kadar kafein awal teh hitam. Etanol 96\% sebanyak $150 \mathrm{ml}$ dimasukkan ke dalam labu destilat $250 \mathrm{ml}$. Sampel sebanyak \pm 3 gram dimasukkan ke dalam kantong soklet kemudian diekstraksi selama $\pm 2,5$ jam dengan menggunakan oil bath. Hasil ekstraksi dicampur dengan larutan suspensi $\mathrm{CaCO}_{3}$ dalam $60 \mathrm{ml}$ air dan mengkisatkan hingga kering dengan menggunakan rotavapor. Residu yang terbentuk dilarutkan ke dalam $100 \mathrm{ml}$ air panas kemudian disaring dalam keadaan panas (dengan vakum) yang dilakukan sebanyak 3 kali pengulangan. Larutan $\mathrm{H}_{2} \mathrm{SO}_{4}$ sebanyak $10 \mathrm{ml}$ diuapkan hingga volumenya menjadi $1 / 3$ volume awal. Melakukan ekstraksi pada filtrat dengan menambahkan $5 \mathrm{ml} \mathrm{CHCl}_{3}$ sebanyak 5 kali. Warna kuning yang terbentuk dibilas dengan $\mathrm{NaOH}$ encer dilanjutkan dengan air. Tahapan selanjutnya adalah menguapkan $\mathrm{CHCl}_{3}$ sehingga diperoleh kafein. Kafein yang diperoleh dikeringkan dalam oven hingga berat konstan.

$$
\% \text { Kafein }=\frac{\text { berat } \text { kafein }}{\text { berat sampel }} \times 100
$$

\section{Hasil dan Pembahasan}

Hasil yang diperoleh pada penelitian ini dalam melakukan pengujian efektifitas penurunan kadar kafein pada teh hitam melalui metode ekstraksi sokletasi yaitu

\section{A. Kadar kafein awal teh hitam}

Kadar kafein teh hitam dari bahan baku diperoleh persentase 3,97\%. Sesuai prasyarat menurut The Food and Drug Administration (FDA) [3] bahwa kadar kafein yang diperbolehkan dalam bahan makanan dan minuman tidak melebihi $0,02 \%$. Sedangkan kadar kafein yang terkandung dalam bahan melebihi ambang batas dengan selisih yang masih cukup tinggi yaitu 3,95\%.

\section{B. Analisis kadar kafein teh setelah ekstraksi}

Hasil ekstraksi dengan metode sokletasi diperoleh data pada Tabel 1 berikut:

Tabel 1. Kadar Kafein Pada Berbagai Konsentrasi Pelarut Etil Alkohol

\begin{tabular}{cc}
\hline $\begin{array}{c}\text { Konsentrasi pelarut } \\
(\boldsymbol{\%})\end{array}$ & Kadar kafein \\
\hline 10 & 0,1099 \\
\hline 20 & 0,0699 \\
\hline 30 & 0,0500 \\
\hline 40 & 0,0206 \\
\hline 50 & 0,0199 \\
\hline
\end{tabular}


Perlakuan ekstraksi dengan tenik sokletasi atau penggunaan soklet sangat efektif menurunkan kadar kafein dengan waktu ekstraksi 2,5 jam. Penuruan kafein Nampak pada Tabel 1 dimana kadar kafein pada teh hitam mengalami penurunan yang cukup signifikan khususnya pada konsentrasi pelarut etil alkohol 50\%.

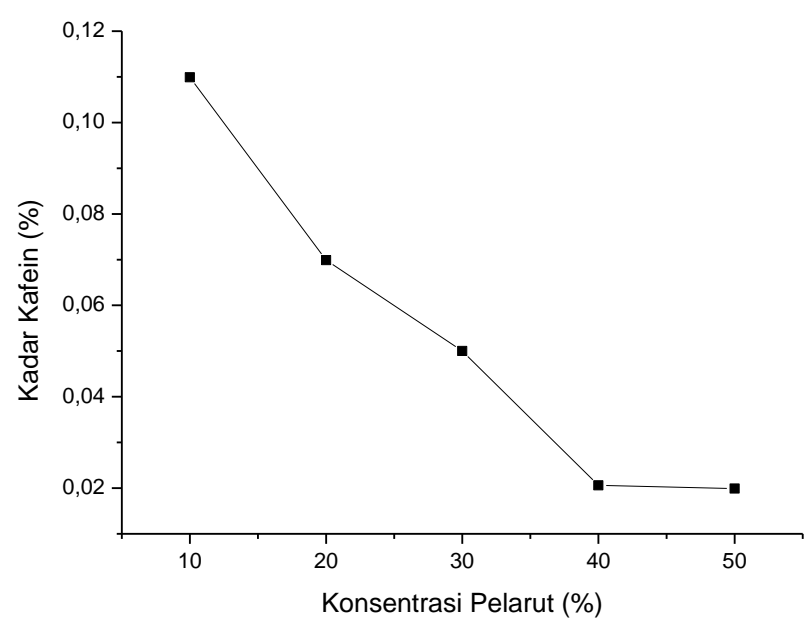

Gambar 1. Konsentrasi Pelarut dengan Penurunan Kadar Kafein

Kandungan kafein semakin turun ketika konsentrasi pelarut ditingkatkan dan akan cenderung konstan pada peralihan kosentrasi pelarut $40 \%$ ke konsentrasi $50 \%$ dengan kadar kafein masing-masing adalah $0,0206 \%$ dan 0,0199\%.

Pada kedua konsentrasi tersebut masuk dalam prasayarat jumlah kandungan kafein pada makanan dan minuman oleh FDA serta memiliki kadar kafein yang masih jauh dari kadar kafein yang dipersyaratkan oleh pemerintah pada SNI 01-7152-2006 [10] bahwa batas maksimum kafein dalam makanan dan minuman adalah $150 \mathrm{mg}$ per hari.

Hasil penurunan kadar kafein tersebut akan memberikan keleluasaan kepada peminum teh untuk tidak mengkhawatrikan akan kandungan kafein pada teh hitam jika penikmat teh mengonsumsi lebih dari dua cangkir seduhan teh hitam per hari.

\section{Kesimpulan}

Berdasarkan penelitian yang telah dilakukan maka dapat disimpulkan bahwa penggunaan pelarut etil alkohol dengan metode ekstraksi sokletasi efektif menurunkan kadar kafein pada teh hitam dari persentase awal teh hitam sebesar 3,79\% menjadi 0,1099\% hingga terendah adalah 0,0199 pada variasi kosentrasi etil alkohol 50\%. Semakin tinggi kosentrasi pelarut etil alkohol maka akan semakin besar pula penurunan kadar kafein pada teh hitam.

\section{Ucapan Terima Kasih}

Ucapan terima kasih diberikan kepada rekan-rekan dosen don analis di jurusan Teknik Kimia Politeknik Negeri Ujung Pandang.

\section{Daftar Pustaka}

[1] Carloni, P., Tiano, L., Padella, L., Bachetti, T., Customu, C., Kay, A., Damiani, E. 2013. Antioxidant Activity of White, Green, and Black Tea Obrained From the Same Tea Cultivar. Food Research International, 53, pp. 900-908.

[2] Rahim. A.A., Nofrizal. S., Saad. Bahruddin. Rapid Tea Catechins And Caffeine Determination by HPLC Using Microwave-Assisted Extraction and Silica Monolithic Column. Food Chemistry, 147, (2014), pp. 262-268.

[3] www.fda.gov

[4] Gardner, E.J., Ruxton, C.H.S., Leeds, A.R. 2007. Black Tea Helpful or Harmful? A Review of the Evidence. European Journal of Clinical Nutrition, Vol. 31, pp. 3-18.

[5] Arwangga, A.A., Asih, I.A.R.A., Sudiarta, I.W. 2016. Analisis Kandungan Kafein pada Kopi di Desa Sesaot Narmada Menggunakan Spketrofotometri UV-VIS. Jurnal Kimia, 10 (1), pp. 110-114.

[6] Komes. D., Horžić. D., Belščak. A., Ganič. Kovačević K., Baljak. A. Determination of Caffeine Content in Tea and Maté Tea by using Different Methods. Czech J. Food Sci. Vol. 27, 2009, pp. 213-216

[7] Vuong. Quan V., Golding. John B., Nguyen. Minh H, Roach. Paul D. Preparation of Decaffeinated and High Caffeine Powders From Green Tea. Powder Technology, 233, (2013), pp.169-175.

[8] El-Shahawi. M.S., Hamza. A., Bahaffi. S.O., Al-Sibaai. A.A., Abduljabbar. T.N. Analysis of Some Selected Catechins and Caffeine In Green Tea by High Performance Liquid Chromatography. Food Chemistry, 134, (2012), pp 2268-2275.

[9] Rasyid, Roslinda., Sanjaya, Winaldi Fitra., Zulharmita. 2013. Penetapan Kadar Kofein Daun Kopi Kawa (Coffea Robusta, Lind). Jurnal Farmasi Higea, Vol. 5, No.2, pp.137-143.

[10] SNI 01-7152-2006 